Asian Review of Social Sciences

ISSN: 2249-6319 Vol.7 No.2, 2018, pp. 37-43

(C) The Research Publication, www.trp.org.in

\title{
Work-Life Balance Factors Influencing the Limited Presence of Women Chefs in Hotel Industry of Bengaluru
}

\author{
Usha Dinakaran \\ Department of Hotel Management, Christ University (Deemed to be University), Bengaluru, Karnataka, India \\ E-mail:ushadinakaran@yahoo.com
}

\begin{abstract}
For women, the difficulty of penetrating historically male-dominated occupations in every sector has always been difficult, and the fact that men are unwilling to accommodate them in those occupations that they dominate has made women to be relegated to the background. When women take up cooking in the professional arena, often they are met with countless challenges and limitations, one of them being the work-life balance. Besides balancing their family life, they face the issue of not being recognized of their calibre at work. Consequently, women chefs are still a rarity in the hotel industry, thereby mirroring the deeply ingraining social and cultural prejudice against women as being the 'weaker sex'. For the purpose of understanding the contributing work-life balance factors towards the limited presence of women chefs within the hotel industry in Bengaluru, each of the individual factors were needed to be analyzed, specifically the extent of their relationship and influence. In the present study, a survey $(\mathrm{N}=123)$ among women chefs working in the Hotel industry of Bengaluru is considered. The study finds that the women chefs are faced with problems in maintaining work-life balance due to several reasons including lack of organizational support leading to disturbed family life, diluted commitment and performance at work place, delayed marriage leading to frustration and family demands leading to expectations of support from peer group at work. Maintaining work-life balance was found to be of utmost importance for women chefs in order to enhance their performance at their workplace.

Keywords: Chef, Women Chef, Hotel, Hotel Industry, Culinary
\end{abstract}

\section{INTRODUCTION}

The growth in hotel industry leads to a heavy demand for enterprising chefs. The New Professional Chef, the Culinary Institute of America's primary textbook, describes chef as a lifelong student, a teacher, a craftsman, a leader and a manager. An open and inquiring mind, an appreciation of the dedication to quality and excellence and a sense of responsibility to self and the community are among the chef's cardinal virtues. The title is one that can only be earned through diligent practice and dedication. Based on the experiences of the researcher, the ascension to the position of a chef is that of a long and hard journey, with a continuous acquisition of knowledge. One of the most pervasive arguments of the researchers is that women are less represented due to the work-family conflict which prevents women from reaching higher levels of representation in the culinary industry (Harris and Giuffre, 2010a).

\section{REVIEW OF LITERATURE}

Allen, (2001) in their study indicates that low compensations and package are only topped by the lack of holidays and leaves to maintain their lives at home. According to the findings of the research, in male dominated occupations, the management ends up having more resources and definitional power to enforce discriminatory practices against women in balancing their life and work, policies and ideologies, and thus, discrimination simply dominates the male dominated and gender-biased management activities.

Guest, (2002) brought out the importance of work-life balance and how they have influenced certain countries in researching this subject and formulating policies. In the perspective of work and life, both the aspects do not reflect on equal weightage but a steady relationship of tolerance and acceptance.

Frone, (2003) reflects on the organizational factors which can impact the overall work-life balance (WLB). WLB initiatives which were found to impact the female employees include; lack of flexible work arrangements, lack of leave arrangements like maternity leave, paternity leave, or leave to take care of the sick and lack of general services like; employee assistant programs, program development based on the family needs. Lack of such initiatives can affect work-life balance of the female employees.

Sandhu and Mehta, (2006) in their research reflect on the importance of work-life balance among women employees. The researcher reflected on four factors which are essential to ensure work-life balance i.e. 1) harmony at work and home; 2) organizational support; 3) family expectations, and 4) Parenting effect and enhancement of professional skills.

Namasivayam and Zhou, (2007) indicated in their research that family roles interfere in the work roles which lead to work-family conflict. The findings indicate that lack of support from the family, especially towards female employees, due to unhealthy relationship with supervisors, or long working hours have demonstrated conflict for the hotel executives.

Rajadhyaksha and Velgach, (2009) in their research reported, that more females in comparison to males reported 
that they faced family interference related to their work. The study also concluded that women with dependent children faced more difficulties in managing work and family life as mothers in India have to spend more time looking after them and their education when compared to their fathers.

Hsieh and Eggers, (2010) in their research indicate that according to most of the managers within the hotel industry, it is common to make sacrifices at the young age in terms of family life in order to achieve success and career advancement. According to the findings, in order to achieve managerial position, one needs to be flexible to work in odd working hours and further all the managers indicated that spousal support was important in alleviating work-life conflict.

Reddy et al., (2010) in their research indicate that lack of family support, lack of co-worker support, and lack of supervisor support are some of the factors affecting worklife balance of women employees. Further, they also indicated that WLB policies, work-family culture and job characteristics are secondary factors which have found to moderately impact the female gender when compared to their male counterparts.

Doble and Supriya, (2010) in their research reflect on five factors which ensure work-life balance for women employees. The study findings are divided into two parts wherein work-based factors included; flexible working time, option to work part time or as a freelancer, and freedom to work from home in case of emergency. Further, the family related factors included; availability of child care facility in the office premises, and flexibility to take care of emergency in the times of crises. Lack of any of these facilities can pose conflicts for the female employees.

Mathew and N.Pachanatha, (2011) in their research indicate that role overload, problems with time management and lack of proper social support are some of the factors which affect work-life balance among women employees across India.

Kehl, (2012) indicates that hotel employees due to continuous working hours are unable achieve work-life balance. They indicated that lack of flexibility in management and scheduling of tasks impact work-life balance.

According to Martin \& Barnard, (2013) psychological barriers inhibit women from reaching the male-dominated occupations, since there is a stereotypical gender role expectations involved. These women suffer from feeling inadequate and having low self-esteem and low selfconfidence that calls for not being able to rise up to the top positions. Further, the researchers highlighted other issues like wage-gap disparity and salary inequities make gender inequality and discrimination to persist, and such issues inhibit women's career progression. Karatepe, (2013) in their research point towards lack of policies and benefits like; paid leaves, premise childcare, health insurance, flexible or compressed working hours to be important factors impacting the overall work-life balance within the hotel industry. The researchers further indicated that lack of support for work-life balance needed for sustainable working environment impacts the overall performance of the employees as well.

Natalie and Janine, (2013) indicated that there are four organizational policies which when worked upon can impact on the work-life balance of the women employees. These include; employee-centric flexible work practices, part-time or flexible working hours, paid and unpaid leave and access to childcare facilities in the office premise. The research also reflected that several organizations are now adopting several policies which are focussed on employee health, safety and welfare, wherein they introduce yoga and stress management practices on regular basis.

Ispeeta and Mitu, (2014) reflected on the importance of organizational policies in influencing work-life balance. Among the factors which were evaluated in the study, work load adjustment, level of exhaustion, preferential working hours, trust/sense of belongingness, social support, lack of crèche facilities in office premises, stress and health related problems, lack of support from children in management of work are some of the factors which affect work-life balance among women employees across different domains.

\section{RESEARCH METHODOLOGY}

\section{A. Objective of the Study}

To comprehend the work-place challenges faced by women chefs in the hotel industry.

\section{B. Hypothesis}

The relationship between various work-life balance factors leading to the limited presence of women chefs in the hotel industry has helped develop the following hypothesis to be tested further in the present research study:-

Null Hypothesis $\left(\mathrm{H}_{\mathrm{N} 1}\right)$ : Factors affecting Work-life Balance of women chefs do not contribute towards their limited presence in the hotel industry.

Alternative Hypothesis $\left(\mathrm{H}_{\mathrm{A} 1}\right)$ : Factors affecting Work-life Balance of women chefs contribute towards their limited presence in the hotel industry.

\section{Design of the Study}

The design of this study is descriptive. The present study employed quantitative research approach, wherein perception and experience of women chefs besides their problems in professional life were obtained. The study was carried out on 123 women chefs working in star hotels in 
Bengaluru, Karnataka. Purposive sampling method was adopted.

\section{RESULTS AND DISCUSSION}

\section{A. Effect of Work Factors and Family Factors on Women Chefs}

Total aggregate score of the responses for all the eight subitems is 3655 against a maximum score of 4920 indicating that the respondents agree that work factors act as a challenge to their professional life. It is evident that women have several responsibilities to manage at their home and that acts as a challenge to them in their workplace. Davidson et al., (2012) pointed out that most of the women quit the job as it is difficult for them to manage the responsibilities at home and work with equal efficiency. Moreover, long working hours and tiredness do not allow them to perform well in their workplace. The respondents nodded in agreement with respect to family factors as well. Total aggregate score of the responses for all the seven subitems is 3260 against a maximum score of 4315 . The result suggests that the respondents agree family factors influence work-life balance. Buddhapriya (2009) studied the challenges of women and pointed out that in India the women face enormous pressure from the family that hinders their work in the workplace. The total actual score of work life balance is $6915(3655+3260)$ and it is close to the total agreed score of $7380(4 \times 15 \times 123)$. Hence the outcome of the overall statement indicates that work life balance problems affects the respondents.

\section{B. Perceptions of Different Groups of Women Chefs on Work-Life Balance}

The age (four level) and marital status (three levels) are considered as independent variables and work life problems faced by women chefs become the dependent variable for the descriptive statistics to understand the perception of age and marital status groups of chefs towards work-life balance.
TABLE I PERCEPTIONS OF AGE AND MARITAL STATUS ON WORK-LIFE BALANCE

\begin{tabular}{|c|c|c|c|c|}
\hline Age & Marital Status & $\mathbf{N}$ & Mean & SD \\
\hline \multirow{4}{*}{ 21-30 Years } & Single & 14 & 2.5333 & 1.15854 \\
\hline & Married & 26 & 2.0487 & 0.65769 \\
\hline & Others & 5 & 1.5200 & 0.64187 \\
\hline & Total & 45 & 2.1407 & 0.88183 \\
\hline \multirow{4}{*}{$31-40$ Years } & Single & 20 & 2.4900 & 0.69156 \\
\hline & Married & 30 & 2.1111 & 1.01065 \\
\hline & Others & 2 & 1.5000 & 0.70711 \\
\hline & Total & 52 & 2.2333 & 0.90801 \\
\hline \multirow{4}{*}{$41-50$ Years } & Single & 7 & 2.7429 & 0.72565 \\
\hline & Married & 5 & 3.6267 & 0.87762 \\
\hline & Others & 2 & 2.5000 & 0.70711 \\
\hline & Total & 14 & 3.0238 & 0.86196 \\
\hline \multirow{4}{*}{ 51-60 Years } & Single & 3 & 1.8667 & 0.78599 \\
\hline & Married & 5 & 1.8267 & 0.80636 \\
\hline & Others & 4 & 2.3833 & 1.25122 \\
\hline & Total & 12 & 2.0222 & 0.92040 \\
\hline \multirow{4}{*}{ Total } & Single & 44 & 2.5015 & 0.87024 \\
\hline & Married & 66 & 2.1798 & 0.94295 \\
\hline & Others & 13 & 1.9333 & 0.91400 \\
\hline & Total & 123 & 2.2688 & 0.92663 \\
\hline
\end{tabular}

In Table I above, women chefs aged between 21 and 30 years, from 31 to 40 years and 51 to 60 years account for 88.6 of the total population with a score range from 2.02 to 2.23 indicating low satisfaction as the values are slightly over 2 . The remaining $11.4 \%$ of women chefs aged from 41 to 50 years have a score of 3.02 indicating a satisfaction level which is neutral. The results are verified with the help of statistical analysis in the following table 4.27.

TABLE II RESULTS OF 4*3 FACTORIAL ANOVA ON WORK-LIFE BALANCE FACTORS

\begin{tabular}{|l|c|c|c|c|c|}
\hline \multicolumn{1}{|c|}{ Source } & $\begin{array}{c}\text { Type III } \\
\text { Sum of Squares }\end{array}$ & Df & Mean Square & F value & P Value \\
\hline Corrected Model & $20.363^{\text {a }}$ & 11 & 1.851 & 2.435 & 0.009 \\
\hline Intercept & 292.563 & 1 & 292.563 & 384.807 & 0.000 \\
\hline Age & 7.662 & 3 & 2.554 & 3.359 & 0.021 \\
\hline Marital status & 1.724 & 2 & 0.862 & 1.134 & 0.326 \\
\hline Age* Marital status & 7.593 & 6 & 1.266 & 1.665 & 0.136 \\
\hline Error & 84.392 & 111 & 0.760 & & \\
\hline Total & 737.911 & 123 & & & \\
\hline Corrected Total & 104.755 & 122 & & \\
\hline
\end{tabular}

The results in Table II above indicate that the four groups included in the variable age reject the null hypothesis ( $f=$
2.554, $\mathrm{df}=3, \mathrm{p}=<.05)$ indicating that while age has a significant influence on the work-life balance of the women 
chefs, their marital status was insignificant as it accepts the null hypothesis ( $\mathrm{f}=0.862 \mathrm{df}=2, \mathrm{p}=<.05$ ) and the combination of these two variables further had no impact on the work-life balance of the chefs as the interaction effect accepts the null hypothesis $(\mathrm{F}=1.266, \mathrm{df}=6, \mathrm{p}=<.05)$. As age group indicates significance, multiple comparison test is carried out.

TABLE III MULTIPLE COMPARISON (PAIRWISE COMPARISONS) TEST FOR FACTORS AFFECTING WORK-LIFE BALANCE

\begin{tabular}{|c|c|c|c|c|c|c|}
\hline \multirow[b]{2}{*}{ Age (I) } & \multirow[b]{2}{*}{ Age (J) } & \multirow[b]{2}{*}{ Mean Difference (I-J) } & \multirow[b]{2}{*}{ Standard Error } & \multirow[b]{2}{*}{ Sig. } & \multicolumn{2}{|c|}{$95 \%$ Confidence Interval for Difference ${ }^{b}$} \\
\hline & & & & & Lower Bound & $\begin{array}{l}\text { Upper } \\
\text { Bound }\end{array}$ \\
\hline \multirow{3}{*}{ 21-30 Years } & $31-40$ years & .000 & .275 & .999 & -.544 & .545 \\
\hline & $41-50$ years & $-.922^{*}$ & .312 & .004 & -1.541 & -.304 \\
\hline & $51-60$ years & .008 & .304 & .978 & -.594 & 611 \\
\hline \multirow{3}{*}{$31-40$ Years } & $21-30$ years & .000 & .275 & .999 & -.545 & .544 \\
\hline & $41-50$ years & $-.923^{*}$ & .347 & .009 & -1.611 & -.235 \\
\hline & $51-60$ years & .008 & .340 & .981 & -.665 & 681 \\
\hline \multirow{3}{*}{ 41-50 Years } & 21 - 30 years & $-.922^{*}$ & .312 & .004 & .304 & 1.541 \\
\hline & 31 - 40 years & $-.923^{*}$ & .347 & .009 & .235 & 1.611 \\
\hline & $51-60$ years & $-.931^{*}$ & .371 & .013 & .197 & 1.665 \\
\hline \multirow{3}{*}{ 51-60 Years } & 21 - 30 years & -.008 & .304 & .978 & -.611 & .594 \\
\hline & $31-40$ years & -.008 & .340 & .981 & .681 & .665 \\
\hline & $41-50$ years & $-.931^{*}$ & .37 & .013 & -1.665 & -.197 \\
\hline
\end{tabular}

1. Based on estimated marginal means. 2. * The mean difference is significant at the .05 level. b. Adjustment for multiple comparisons: Least Significant Difference (equivalent to adjustments)

\section{Rotated Component Matrix Factors Affecting Work-Life Balance}

TABLE IV ROTATED COMPONENT MATRIX OF FACTORS AFFECTING WORK-LIFE BALANCE

\begin{tabular}{|c|c|c|c|}
\hline $\begin{array}{c}\text { Variable } \\
\text { No } \\
\end{array}$ & Variables & $\begin{array}{c}\text { Compo- } \\
\text { nent } 1 \\
\end{array}$ & $\begin{array}{c}\text { Compo- } \\
\text { nent } 2 \\
\end{array}$ \\
\hline \multicolumn{4}{|c|}{ Work Factors (Component 1) } \\
\hline V 33 & Lack of role clarity resulting in blame game with hostile comments & .881 & \\
\hline V 38 & Inadequate work - life balance policies & .880 & \\
\hline V 35 & Work exhaustion causing negligence of elders at home & .887 & \\
\hline V 31 & Long working hours leading to lack of socialization and quality family life & .871 & \\
\hline V 36 & Lack of Organizational support leading to disturbed family life & .861 & \\
\hline V 32 & Unfriendly working hours and exhaustion deprives contribution to family & .852 & \\
\hline V 34 & Emphasis on 'face time' leading to poor family life & .842 & \\
\hline V 37 & Diluted commitment and performance at work-place & .833 & \\
\hline \multicolumn{4}{|c|}{ Family Factors (Component 2) } \\
\hline V 44 & Unavoidable absenteeism due to lack of sabbatical leave & & .876 \\
\hline V 39 & Finding time for hobbies and extended family relationships difficult & & .871 \\
\hline V 42 & Family pressure leading to unhealthy professional relationship with supervisors & & .864 \\
\hline V 43 & Family demands leads to support from peer group at work & & .863 \\
\hline V 45 & Denial of flexibility in balancing family and work dilutes loyalty to organization & & .863 \\
\hline V 40 & Delayed marriage leading to frustration & & .853 \\
\hline V 41 & Work deadlines coupled with lack of family understanding and support & & .849 \\
\hline
\end{tabular}

Multiple comparison test in Table III enables comparison of the pair wise differences. Age group $21-30$ years when compared to $41-50$ years shows presence of significant difference $(\mathrm{p}<.05)$. Age group 31 - 40 when compared with age group $41-50$ years, there is a significant diffence $(\mathrm{p}=.009)$. Hence the perception is different. 
In the above Table $\mathrm{V}$ the Levene's test is not significant with a $\mathrm{p}$ value of $53.9 \%$. This indicates that all the groups are having equal variant. It is one of the assumptions, if met, Factorial ANOVA is accepted.

TABLE V LEVENE'S TEST FOR FACTORS AFFECTING WORK-

\begin{tabular}{|c|c|c|c|}
\hline \multicolumn{5}{|c|}{ LIFE BALANCE } \\
\hline 0.904 & 11 & 111 & 0.539 \\
\hline
\end{tabular}

The rotated component matrix, undertaken to extract the important factors, as seen in Table IV showed that there are two main components, work factors and family factors under this objective each with eight and seven variables respectively, correlated among them. The first component variable is explained by 88.20 whereas the second component variables are explained by $7.87 \%$.

\section{Fitness of Model for Factors Affecting Work Life Balance}

After observing very good loading and explanation of variables by more than the standard in rotated components matrices, we can check the individual construct reliability.

TABLE VI RELIABILITY TEST RESULTS OF WORK FACTORS AND FAMILY FACTORS

\begin{tabular}{|c|c|c|c|}
\hline \multicolumn{2}{|c|}{ Work Factors } & \multicolumn{2}{c|}{ Family Factors } \\
\hline Cronbach's Alpha & N of Items & Cronbach's Alpha & N of Items \\
\hline .994 & 8 & .993 & 7 \\
\hline
\end{tabular}

In Table VI, the first component, work factors have eight variables and the second component, family factors have seven variables and all the variables are tested with help of reliability test. If the Cronbach's reliability is greater than
0.7 , it is good but the above sets in Table VI indicate Cronbach's are 0.994 and 0.993 for the two components respectively which are more than the expected.

E. Impact Factors Affecting Work-Life Balance on the Presence of Women Chefs

TABLE VII REGRESSION RESULTS OF FACTORS AFFECTING WORK-LIFE BALANCE

\begin{tabular}{|c|c|c|c|c|c|c|c|c|}
\hline \multirow{2}{*}{\multicolumn{2}{|c|}{ Model }} & \multicolumn{2}{|c|}{$\begin{array}{l}\text { Unstandardized } \\
\text { Coefficients }\end{array}$} & \multirow{3}{*}{$\begin{array}{c}\begin{array}{c}\text { Standar } \\
\text { dized } \\
\text { Coefficie } \\
\text { nts }\end{array} \\
\text { Beta }\end{array}$} & \multirow{3}{*}{$\begin{array}{c}\mathbf{t} \\
-0.069\end{array}$} & \multirow{3}{*}{$\begin{array}{c}\text { Sig } \\
0.945\end{array}$} & \multicolumn{2}{|c|}{ Collinearity Statistics } \\
\hline & & \multirow{2}{*}{$\begin{array}{c}\boldsymbol{B} \\
-0.002\end{array}$} & \multirow{2}{*}{$\begin{array}{c}\begin{array}{c}\text { Standard } \\
\text { Error }\end{array} \\
0.24\end{array}$} & & & & Toloromco & VIT \\
\hline 1 & Constant & & & & & & & \\
\hline & Variable 36 & 0.331 & 0.24 & 0.355 & 13.917 & .000 & 0.144 & 6.923 \\
\hline & Variable 37 & 0.206 & 0.24 & 0.223 & 8.740 & .000 & 0.144 & 6.930 \\
\hline & Variable 40 & 0.230 & 0.28 & 0.243 & 8.029 & .000 & 0.107 & 9.308 \\
\hline & Variable 43 & 0.235 & 0.28 & 0.239 & 8.321 & .000 & 0.114 & 8.764 \\
\hline \multicolumn{3}{|c|}{ F Value } & \multicolumn{6}{|l|}{2628.044} \\
\hline \multicolumn{3}{|l|}{ Sig } & \multicolumn{6}{|l|}{0.000} \\
\hline \multicolumn{3}{|l|}{$\mathrm{R}$} & \multicolumn{6}{|l|}{.994} \\
\hline \multicolumn{3}{|c|}{ R Square } & \multicolumn{6}{|l|}{.989} \\
\hline \multicolumn{3}{|c|}{ Adjusted R Square } & \multicolumn{6}{|l|}{.989} \\
\hline \multicolumn{3}{|c|}{ Durban Watson } & \multicolumn{6}{|l|}{1.981} \\
\hline \multicolumn{3}{|c|}{ Predictors (Constant) } & \multicolumn{6}{|c|}{ Variables $36,37,40,43$} \\
\hline \multicolumn{3}{|c|}{ Dependent Variable } & \multicolumn{6}{|c|}{ Work-Life Balance (D3) } \\
\hline
\end{tabular}

Table VII represents the regression results of work life balance issues. Based on the above table, the $F$ value 2628.044 and $p<.05$ indicate there is relationship between dependent variable and the predictor variables. Since the probability of $\mathrm{F}$ statistics is $\leq$ the level of significance (0.05), the null hypothesis that there is no linear relationship between the independent and dependent variables is rejected. The alternate hypothesis that there is relationship between the variables is supported. All the four variables included in the analysis against the outcome variable, are significant at $1 \%$ significant level with positive relationship (unstandardized B value are all positive). For even one unit of increase of the independent variables, (1) lack of organizational support leading to disturbed family life, (2) 
diluted commitment and performance at work place, (3) delayed marriage leading to frustration and (4) family demands leading to expectations of support from peer group at work, the dependent variable increases by $0.331,0.206$, 0.230 and 0.235 respectively.

It is evident that lack of organizational support is leading to disturbed family life, diluted commitment and performance at work place, delayed marriage leading to frustration and family demands leading to expectations of support from peer group at work. Such long working hours lead to both mental and physical exhaustion and that does not permit the woman to take part in social or family life enthusiastically (Ko 2012). Young women chefs with offspring find it difficult to manage their life shouldering the additional duty of running the household (Lopez - Claros \& Zahidi, 2005). Though the couples share the duty of childcare in families with dual income, women ultimately become the primary caregiver (Budworth, Enns, \& Rowbotham, 2008). Ultimately it becomes the primary responsibility of women to manage her work and life making it difficult to overcome the associated problems.

\section{FINDINGS}

In terms of work factors, the women chefs agree that work factors act as a challenge to their professional life. In terms of family factors, the women chefs agree to the fact that family factors influence work- life balance. Overall the women chefs agree that work life balance problems affect them. The perception of women chefs in the four groups of age has a significant influence on the work - life balance while there is no significant difference in the influence of the three marital status groups. The two, work factors and family factors were significant towards Work-Life Balance.

Lack of organizational support leading to disturbed family life, diluted commitment and performance at work place, delayed marriage leading to frustration and family demands leading to expectations of support from peer group at work contributed the most towards the problems of women chefs maintaining work-life balance within the hotel industry. Out of the four variables, lack of organizational support leading to disturbed family life and family demands leading to expectations of support from peer group at work, have a higher influence than the other variables on the presence of women chefs in the hotel industry.

\section{RECOMMENDATIONS}

With increasing social media pressure for establishing gender equal workplaces, the management of hotel industry could focus on introducing changes in their company policies and even make efforts to change the work culture and environment, provide more flexibilities for women, be more considerate towards the work-life balance pressures and most importantly, provide equal opportunities for the women chefs to proceed up the professional ladder in the hotel industry. Women chefs should also comprehend that inequality in work and life is a natural phenomenon which is progressive with different phases of personal and professional life. The onus is on the women chefs to thoroughly analyse and evaluate their personal needs, professional capability and potential besides the opportunities obtainable within the hotel industry and outside before compromising on work and family. They need to evaluate and understand their requirements at each stage of their life and choose the right blend of work and life activities for healthier integration of work and life.

\section{CONCLUSION}

Conclusions can be drawn from the findings of both primary and secondary data analysis. Factors which were found to impact the overall work-life balance among women chefs include long working hours leading to lack of socializing, lack of time for hobbies and leisure, inadequate work-life balance policies and work deadlines and lack of family support. This situation in the male-dominated hotel industry for women chefs is further exacerbated since the male dominance encourages definitional power to enforce discriminatory practices against women (Martin \& Barnard, 2013).

\section{REFERENCES}

[1] Allen, T. D. (2001). Family-Supportive Work Environments: The Role of Organizational Perceptions. Journal of Vocational Behavior, 58(3), 414-435.

[2] Buddhapriya, Sanghamitra. (2009). Work-Family Challenges and Their Impact on Career Decisions: A Study of Indian Women Professionals. Vikalpa 34(1): 31-45.

[3] Budworth, M., Enns, R., \& Rowbotham, K. (2008). Shared Identity and Strategic Choice in Dual Career [3] Couples. Gender in Management: An International Journal, 23(2), 103 - 119.

[4] Davidson, Sarah et al. (2012). Women in Orthodontics and WorkFamily Balance: Challenges and Strategies. Journal of the Canadian Dental Association. 78(1).

[5] Dembe, A. E., Erickson, J. B., Delbos, R.G \& Banks, S. M. (2005) The impact of overtime and long work hours on occupational injuries and illnesses: new evidence from the United States. Occupational and Environmental Medicine, 62(9), 588-597.

[6] Frone, M. R. (2003). Work-family balance. Handbook of Occupational Health Psychology, Washington, D. C.: American Psychological Association, 143(62).

[7] Guest, D. E. (2002). Perspectives on the study of work-life balance Social Science Information, 41, 255-279.

[8] Hsieh, Y, and P. D. Eggers. (2010). Coping Strategies Used by Lodging Managers to Balance Work and Personal Lives: An Exploratory Study. International Journal of Hospitality \& Tourism Administration 11, 39-58.

[9] Karatepe, O. M. (2013). The Effects of Work Overload and WorkFamily Conflict on Job Embeddedness and Job Performance: The Mediation of Emotional Exhaustion. International Journal of Contemporary Hospitality Management 25(4), 614-34.

[10] Kehl, Tim. (2012). 12 Key Strategies to Achieving a Work-Life Balance. Industry Week.

[11] Ko, Wen Hwa. (2012). the Relationships among Professional Competence, Job Satisfaction and Career Development Confidence for Chefs in Taiwan. International Journal of Hospitality Management 31(3), 1004-11.

[12] Lopez - Claros, A., \& Zahidi, S. (2005). Women's EmpowermentMeasuring the Global Gender Gap: Harvard Business Review.

[13] Martin, Phiona, and Barnard, Antoni. (2013). The Experience of Women in Male-Dominated Occupations: A Constructivist Grounded Theory Inquiry. SA Journal of Industrial Psychology 39(2): 1-12. 
[14] Mathew, R. V., \& N. Pacnchanatha. (2011). Work Life Balance Issues among the Women Entrepreneurs in South India. Asian Academy of Management Journal 16(2): 77- 105.

[15] Mills, Julie E., Suzanne Franzway, Judith Gill, \& Rhonda Sharp. (2013). Challenging Knowledge, Sex and Power: Gender, Work and Engineering. Routledge.

[16] Namasivayam, K., \& X Zhou. (2007). An Investigation of the Moderating Effects of Organizational Commitment on the Relationships between Work-family Conflict and Job Satisfaction among Hospitality Employees in India. Tourism Management 28, $1212-23$.
[17] Natalie, Skinner, \& Chapman Janine. (2013). Work-Life Balance and Family Friendly Policies. Evidence Base Evidence B(4).

[18] Rajadhyaksha, U., \& S. Velgach. (2009). Gender, Gender Role Ideology and Work-Family Conflict in India. Chicago, USA: Academy of Management.

[19] Reddy, N Krishna et al. (2010). Work-Life Balance among Married Women Employees. Indian journal of psychological medicine 32(2): $112-18$.

[20] Sandhu, H. S., \& Ritu Mehta. (2006). Work-Family Conflict among Women Executives in Service Sector: An Empirical Study. Journal of Advances in Management Research 3(2): 68-80. 